\title{
Temporal dynamics of coral and algal cover and their drivers on a coral reef of Gorgona Island, Colombia (Eastern Tropical Pacific)
}

\author{
Fernando A. Zapata
}

Grupo de Investigación en Ecología de Arrecifes Coralinos, Departamento de Biología, Universidad del Valle, Cali, Colombia

Inaugural article by corresponding member of the Colombian Academy of Exact, Physical and Natural Sciences in June 7, 2017

\begin{abstract}
Coral reefs are highly dynamic ecosystems often affected by diverse natural disturbances. However, dramatic declines in coral cover during recent decades raise the question of whether such declines are due to increasing anthropogenic impacts. To this end, the dynamics of coral and algal cover were studied based on data collected between 1998-2014 from 20 fixed 10-m transects at two depths in two sites of La Azufrada, a coral reef free of local human impacts, located at Gorgona Island, Colombia. Coral cover declined from 66.9 \% in 1998 to $39.4 \%$ in 2008, but then increased to $50.7 \%$ in 2014. Fleshy and turf algae were low between $1998-2004$, increased to $49.5 \%$ in 2007 , and then declined to $<33.0 \%$. Crustose coralline algae were lowest until 2009 when they increased as fleshy and turf algae decreased. Temporal variation was different between depths with shallow areas exhibiting major declines in coral cover until 2008 but a significant recovery since then. In contrast, coral cover in deep areas declined only slightly. Prolonged subaerial exposure of corals during extreme low tides appears to drive a cycle of coral disturbance and recovery. Coral growth makes the reef flat prone to subaerial exposure, after which corals bleach, die and are colonized by filamentous turf and fleshy algae. Sea urchins and herbivorous fishes increase their abundance in response to increased algal cover and control algal growth, leaving the substrate covered by crustose coralline algae and making it suitable for settlement by sexually-produced coral larvae. Fragmentation by both physical and biological agents (such as corallivores) enhances coral recruitment and the reef enters a coral recovery phase. Although this reef is resilient to subaerial exposure because it is protected from anthropogenic perturbations, increasing threats from global climate change may compromise its future resilience. (c) 2017. Acad. Colomb. Cienc. Ex. Fis. Nat.
\end{abstract}

Key words: Coral reefs; Disturbance; Recovery; Spatial variation; Subaerial exposure; Temporal dynamics.

Dinámica temporal de la cobertura de corales y algas y sus impulsores en un arrecife coralino de Isla Gorgona, Colombia (Pacífico Tropical Oriental)

\section{Resumen}

Los arrecifes coralinos son ecosistemas altamente dinámicos, a menudo afectados por diversas perturbaciones naturales. Sin embargo, descensos dramáticos en la cobertura coralina durante décadas recientes llevan a preguntar si tales descensos han sido causados por crecientes impactos antropogénicos. Con este fin, la dinámica de la cobertura de coral y algas se estudió a partir de datos recolectados entre 1998-2014 de 20 transectos fijos de $10 \mathrm{~m}$ a dos profundidades en dos sitios de La Azufrada, un arrecife coralino libre de impactos humanos locales, situado en Isla Gorgona, Colombia. La cobertura coralina disminuyó de 66,9 \% en 1998 a 39,4 \% en 2008, pero luego aumentó a 50,7 \% en 2014. La cobertura de algas carnosas y de césped fue baja entre 1998-2004, aumentó a 49,5 \% en 2007 y luego disminuyó a $<33,0 \%$. Las algas coralinas incrustantes fueron las más escasas hasta 2009, cuando aumentaron al disminuir las algas carnosas y de césped. La variación temporal fue diferente entre profundidades con las áreas someras exhibiendo los mayores descensos en la cobertura coralina hasta 2008, pero una recuperación significativa desde entonces. En contraste, la cobertura coralina en áreas profundas disminuyó sólo ligeramente. La exposición subaérea prolongada de los corales durante mareas bajas extremas parece impulsar un ciclo de perturbación y recuperación de los corales. El crecimiento de los corales hace que el arrecife sea más propenso a la exposición subaérea, después de lo cual los corales se blanquean, mueren y son colonizados por algas filamentosas y carnosas. Los erizos de mar y los peces herbívoros aumentan su abundancia en respuesta al aumento de la cobertura de algas y controlan el crecimiento de algas, dejando el sustrato cubierto por algas coralinas incrustantes que lo adecúan para el asentamiento de larvas de coral producidas sexualmente. La fragmentación por agentes físicos y biológicos (como los coralívoros) incrementa el reclutamiento de coral y el arrecife entra en una fase de recuperación coralina. Aunque este arrecife es resiliente a la exposición subaérea porque está protegido de perturbaciones antropogénicas, las crecientes amenazas del cambio climático global pueden comprometer su futura resiliencia. (C) 2017. Acad. Colomb. Cienc. Ex. Fis. Nat.

Palabras clave: Arrecifes coralinos; Dinámica temporal; Exposición subaérea; Perturbación; Recuperación; Variación espacial. 


\section{Introduction}

Coral reefs were once believed to be highly organized, stable, biologically accommodated assemblages of coevolved species coexisting at an equilibrium under benign and predictable environmental conditions (Grassle, 1973; Connell, 1978; Smith, 1978). Nearly two decades later this view had changed drastically and coral reefs were perceived as highly dynamic, non-equilibrium assemblages with dramatic changes often occurring as part of natural cycles of disturbance and recovery over varied spatial and temporal scales (Connell, 1978, 1997; Aronson and Precht, 1997; Brown, 1997a; Connell, et al., 1997, 2004; Pandolfi, 1999). While change was recognized as a normal feature of coral reefs, signs of degradation began to be observed in the late 1970s and early 1980s (Gladfelter, 1982; Glynn, et al., 1988; Porter and Meier, 1992) and have continued to increase at alarming rates ever since (Bryant, et al., 1998; Wilkinson, 2008; Jackson, et al., 2014). Evidence of such degradation includes a continuing decline of live coral cover and a concomitant increase of benthic algae (Hughes, 1994; Gardner, et al., 2003; Bruno and Selig, 2007; De'ath, et al., 2012), massive mortalities of functionally important organisms (Gladfelter, 1982; Lessios, et al., 1984; Carpenter, 1990; Liddell and Ohlhorst, 1992; Hughes, 1994), increased incidence of coral diseases (Santavy and Peters, 1997; Sutherland, et al., 2004), depletion of fisheries resources (Rogers, 1985; Hughes, 1994) and an increase in the frequency, intensity and geographic distribution of coral bleaching events (Williams and Bunkley-Williams, 1990; Glynn, 1993; Brown, 1997b; Glynn, et al., 2001; McWilliams, et al., 2005).

In general, the causes of coral reef degradation are strongly associated with increases in anthropogenic stressors such as increased human population densities near coral reefs (Birkeland, 1997; Jackson, et al., 2014), coastal pollution, continental runoff and sewage discharge that increase turbidity, sedimentation and nutrient loads in coastal zones (Szmant, 2002; Fabricius, 2005), overfishing of commercially valuable organisms (Munro, 1983; Jennings and Polunin, 1996; Jackson, et al., 2001; Pandolfi, et al., 2003), recreational activities that damage or disturb coral reef organisms (Díaz, et al., 2000; Rouphael and Inglis, 2002), the introduction of invasive species (Jackson, et al., 2014) and ocean warming (Baker, et al., 2008) and acidification (Hoegh-Guldberg, et al., 2007; Veron, 2011). Even though natural perturbations such as tropical storms, hurricanes, extreme-low-tide subaerial exposures, earthquakes and tsunamis have undoubtedly played a role in such degradation (Hughes, 1994; Jackson, et al., 2014; Miller, 2015), it is now thought that the impacts of natural disturbances are being exacerbated by their interaction with anthropogenic pressures (Nyström, et al., 2000; Hughes, et al., 2003; Pandolfi, et al., 2003). For instance, human-induced global warming appears to be increasing the intensity and frequency of El Niño warming events and the frequency of hurricanes and crown- of-thorns (Acanthaster planci) outbreaks (Enfield, 2001; Aronson, et al., 2002; Harvell, et al., 2002; Hughes, et al., 2003; Buddemeier, et al., 2004).

Most Colombian coral reefs have also shown signs of degradation (Díaz, et al., 2000; Jackson, et al., 2014). In the Colombian Caribbean, for instance, live coral cover decreased by an average of $~ 38 \%$ during the last three decades of the 20th century reaching an average of 20-30 \% in most areas (Garzón-Ferreira and Kielman, 1994; Garzón-Ferreira, 1997; Díaz, et al., 2000; Garzón-Ferreira, et al., 2002a); these values have remained relatively constant between 1998 and 2013 (Bastidas-Salamanca, et al., 2014). While the decline of Colombian Pacific coral reefs was much more severe due to the massive coral mortality that occurred throughout the Eastern Tropical Pacific (ETP) during the 1982-83 El Niño event (Glynn, 1990; Vargas-Ángel, et al., 2001), recovery to pre-disturbance levels was achieved within a decade (Zapata, et al., 2001; Zapata and VargasÁngel, 2003) and levels of live coral cover are relatively high ( $\geq 50-74 \%$ average; Rodríguez-Ramírez, et al., 2006; Zapata, et al., 2010). Although several studies have described many of Colombian coral reefs and documented their most significant changes (Garzón-Ferreira and Kielman, 1994; Díaz, et al., 1995, 1996, 2000; Zea, et al., 1998; Zapata, et al., 2001, 2010; Zapata and VargasÁngel, 2003), the lack of detailed quantitative assessments through time has hampered the identification of drivers of change. In this paper, I use data collected by the National Monitoring System for the Coral Reefs of Colombia (SIMAC for its Spanish acronym; Garzón-Ferreira and RodríguezRamírez, 2010) to describe the dynamics of coral and algal cover during a 17 yr-long (1998-2014) time series at La Azufrada reef, one of the largest and best developed coral reefs of Gorgona Island, in the Colombian Pacific Ocean (Zapata and Vargas-Ángel, 2003). I address the following questions: What are the dynamics of coral and algal cover at La Azufrada coral reef? What are the major drivers of these dynamics? What do these dynamics tell us about the resilience of this coral reef?

\section{Materials and methods}

Study area. The largest and most developed coral reefs of the Colombian Pacific occur at Gorgona Island $\left(2^{\circ} 58^{\prime}\right.$ $\mathrm{N}, 78^{\circ} 10^{\prime} \mathrm{W}$ ), a continental island located $30 \mathrm{~km}$ off the Colombian mainland, in one of the rainiest regions of the world, near the southern end of Panama Bight (Glynn, et al., 1982; Díaz, et al., 2000; Zapata and Vargas-Ángel, 2003; Figure 1). The latitudinal displacement of the Intertropical Convergence Zone (ITCZ) strongly influences climatic and oceanographic conditions at Gorgona Island, which are notably seasonal. Mean annual precipitation at Gorgona Island exceeds $6600 \mathrm{~mm}$ (Blanco, 2009). Mean monthly precipitation is lower between January and April, when the ITCZ is at its southernmost position, coinciding with a shallow $(7.5 \mathrm{~m})$ thermocline, and cold and high salinity 


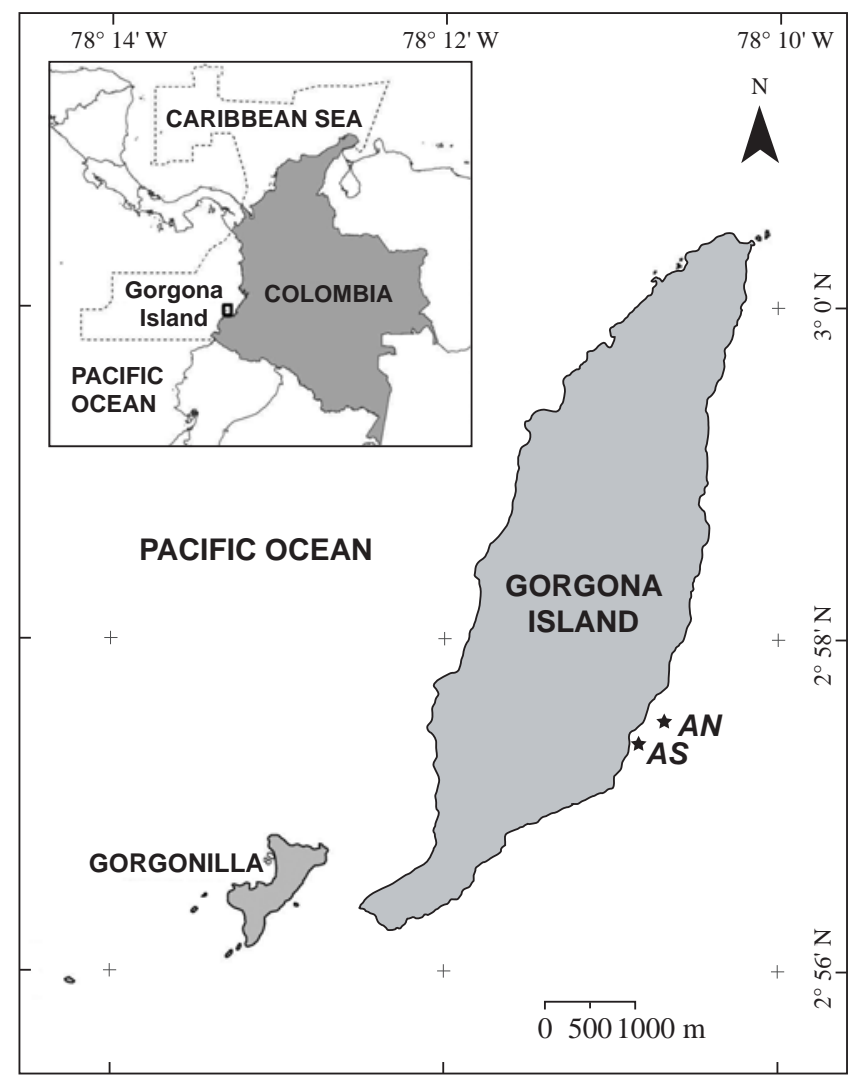

Figure 1. Location of Gorgona Island and monitoring sites (AN and AS) at La Azufrada coral reef, Gorgona Island, Colombia.

sea surface waters. The rest of the year, when the ITCZ is in the north, precipitation is higher, the thermocline is deeper $(47 \mathrm{~m})$ and sea surface waters are warm and have low salinity (Giraldo, et al., 2008; Blanco, 2009). Sea surface temperatures around Gorgona vary between 26 and $29{ }^{\circ} \mathrm{C}$, occasionally decreasing to $<19{ }^{\circ} \mathrm{C}$ during upwelling events that occur during the dry season (Díaz, et al., 2001; Zapata, 2001; Giraldo, et al., 2008), or increase to $30-32{ }^{\circ} \mathrm{C}$ during anomalous conditions associated with El Niño events (Vargas-Ángel, et al., 2001). Seawater salinity at Gorgona is relatively low and variable (29-33) compared to that of the open ocean, but it is nonetheless higher and more stable than that of the mainland coast, which is usually $<$ 20 (Devis-Morales, et al., 2002). In fact, Gorgona Island is one of the localities with coral reefs and lowest salinities in the world (Kleypas, et al., 1999). The tidal regime at Gorgona is semidiurnal with a maximum vertical range of $\sim 5.7$ m (IDEAM, 2000). Besides strong El Niño warming events that periodically cause severe coral bleaching and mortality (Glynn, 1990; Vargas-Ángel, et al., 2001), the most significant physical perturbation on Gorgona Island coral reefs are repeated subaerial exposures during extreme low tides, which most often occur between January and April and occasionally cause coral bleaching and mortality on the shallowest portions of reefs (Zapata, et al., 2001;
Zapata and Vargas-Ángel, 2003; Castrillón-Cifuentes, et al., 2017). Gorgona Island is a National Natural Park and it is well-protected from local human impacts.

Study sites. La Azufrada reef, located on the leeward side of the island, is the largest (11.2 ha) continuous coral reef of Gorgona Island. This fringing reef extends approximately for $1 \mathrm{~km}$ along the eastern coast. Following an inshore-offshore transect, the reef has an $\sim 80-130 \mathrm{~m}$ reef flat with high pocilloporid coral cover, a sloping reef front also dominated by pocilloporids and an outer reef base where massive species of the genus Pavona and Gardineroseris occur in patches (Glynn, et al., 1982; Zapata, 2001; Zapata and Vargas-Ángel, 2003). Two study sites were selected on this reef in November 1998 based on their good state of conservation and similarity in reef development. The first site (La Azufrada North; Figure 1) is located in the northern portion of the reef near a circular depresion (known locally as El Hueco), which is a notable, persistent feature of this reef (Glynn, et al., 1982; Zapata, 2001). The second site (La Azufrada South) is located in the southern section of the reef about $400 \mathrm{~m}$ from the north site (Figure 1). At each site, a shallow and a deep plot were established, each consisting of five 10-m long transects haphazardly laid out and permanently marked with stainless steel rods driven into the substrate, one at each end of each transect. The shallow plot was located on the reef flat at $\sim 0.5 \mathrm{~m}$ below the Mean Lower Low Water 0-m tidal datum (IDEAM, 2000), while the deep plot was located further offshore at the interface between the reef front and the outer reef base at $\sim 4 \mathrm{~m}$ below the $0-\mathrm{m}$ tidal datum. The complete setup consisted of a total of two sites, four plots and 20 permanent transects. More detailed information on the two sites may be found in Zapata, et al. (2010).

Data collection. Data on the benthic cover and abundance of herbivorous fishes were collected once a year between 1998 and 2014. Data on sea urchin abundance were collected between 2002 and 2014. All data was obtained each year during a single week of August - November (depending on the year) by a team of 5-8 divers. The cover of different benthic organisms (mostly live coral and algae) was estimated using the continuous line intercept, chain-transect method (Loya, 1978). Live coral cover represents mostly the abundance of pocilloporids because these are the dominant corals at $\mathrm{La}$ Azufrada reef, except at the deep plot of the north site, where agariciids (mostly species of Pavona) are common. While fleshy and turf algae were considered as separate categories during data collection, for analysis they were combined in a single category because fleshy algae were relatively scarce. Calcareous algae were overwhelmingly crustose coralline algae (CCA) and were considered separately because of their important role facilitating coral recruitment (Birrell, et al., 2008). Sea urchins were counted since 2002 along a $1 \mathrm{~m}$-wide band along each of the two sides of each $10-\mathrm{m}$ permanent transect $\left(20 \mathrm{~m}^{2}\right.$ area per transect). Herbivorous fishes were visually censused since 1998 along $30 \times 2 \mathrm{~m}$ 
belt transects haphazardly placed within each plot each year. Two to ten transects were censused at each plot each year for a total of 535 fish visual censuses over the study period. Methods followed protocols modified from CARICOMP (2001; see also Garzón-Ferreira and Rodríguez-Ramírez, 2010, Zapata, et al., 2010).

Statistical analyses. The benthic cover (coral, fleshy and turf algae, and crustose coralline algae) data were analyzed with a linear mixed model with two fixed factors, each with two levels: site (North and South) and depth (shallow and deep plots). Because the same transects were repeatedly sampled every year, this design additionally included one within-subject, repeated measures factor (years) with 17 levels representing the number of consecutive years. The model also included a variance heterogeneity term as a function of year to account for the heteroscedasticity structure within years. This analysis was performed with package nlme (Pinheiro, et al., 2017) in the R software Ver. 3.3.1 (R Core Team, 2016). Analysis of residuals indicated that assumptions of normality and homoscedasticity were satisfied only by the live coral cover data, but not by the fleshy and turf algae or CCA data. The heteroscedasticity structure within years included in the models improved homoscedasticity of residuals in the live coral and CCA data but not in the fleshy and turf algae data. Since the arcsine square root transformation is no longer recommended for statistical analyses of percentages (Warton and Hui, 2011) and the logit transformation did not improve normality and heteroscedasticity of residuals for both types of algae, the analyses reported are based on the original percentage data for all variables. The total abundance of sea urchins or herbivorous fishes was analyzed with a three-way factorial (13 or 17 years, respectively, x 2 sites x 2 depths) generalized linear mixed model with a negative binomial error distribution and a Log-link function using the R software package lme4 (Bates, et al., 2015; R Core Team, 2016). For the sea urchin data, transect was used as a random effects factor because the same transects were sampled repeatedly through the years. In contrast, the model fitted to the herbivorous fish data did not include a repeated measures structure because fish were not censused on the same transects every year.

\section{Results}

Live coral was the dominant component of the benthic cover on La Azufrada coral reef throughout the 17 years of study except in 2007, when fleshy and turf algae, the second mostimportant component, was more abundant than coral (Figure 2). Calcareous algae represented the third major component of benthic cover, particularly since 2009. Both coral and algal cover varied significantly through the years (Table 1). Overall (all sites and depths combined), mean percent live coral cover declined from $66.9 \pm 4.4 \%$ ( \pm SE) in 1998 to a minimum of $39.4 \pm 7.8 \%$ in 2008 , but showed an increasing trend since then reaching 50.7 ( $\pm 5.7 \%$ ) in 2014. Thus, during the 17 years there was a net absolute loss of live coral cover of $16.2 \%$, representing a relative loss of $24.2 \%$ of the coral existing in 1998. At the same time, fleshy and turf algae tended to show temporal patterns of variation opposite those of coral because these two components of benthic cover were negatively correlated every year $(\mathrm{r}=-0.592-$ $-0.955, \mathrm{p} \leq 0.006, \mathrm{~N}=20$ within any given year). Overall, fleshy and turf algal cover was below $29.0 \%$ between 1998 2004, and above $33.0 \%$ between 2005-2008, reaching a peak of $49.5 \pm 8.8 \%$ in 2007 and then declining to levels below $33.0 \%$ (Figure 2). The net absolute change in fleshy and turf algal cover between 1998 and 2014 was of only $0.6 \%$, which represents a $2.3 \%$ increase relative to 1998 . Crustose coralline algae also varied through the study period between a minimum yearly mean of $3.4 \pm 0.5 \%$ in 1998 and a maximum yearly mean of $26.0 \pm 6.7 \%$ in 2009 . By 2014 the mean cover by calcareous algae was $18.8 \pm 3.8 \%$ indicating an absolute net increase of $15.4 \%$ or a $452.9 \%$ increase relative to 1998 levels.

Temporal and spatial variation in coral and algal cover. Coral cover was higher on the south than on the north site throughout the study period (Table 1; Figure 3). Overall (all years and depths combined) mean coral cover was $61.0 \pm$ $6.1 \%$ on the south site and $42.2 \pm 6.1 \%$ on the north site. This difference was maintained throughout the study period as indicated by the lack of a significant year $\mathrm{x}$ site interaction (Table 1). Both sites exhibited trends of coral cover loss through the entire study period like that observed for the whole reef, with a net absolute decrease of $18.1 \%$ in the north and $14.2 \%$ in the south, which represent net decreases of $30.9 \%$ and $18.9 \%$ relative to 1998 levels, respectively. Both sites also showed a similar pattern of coral decrease from 1998 to 2008 and a recovering trend afterwards.

Based on all sites and years combined, there were pronounced differences in mean coral cover between depths $(34.8 \pm 6.1 \%$ in shallow vs $68.5 \pm 6.1 \%$ in deep plots; Table $1)$. While coral cover in shallow areas declined dramatically

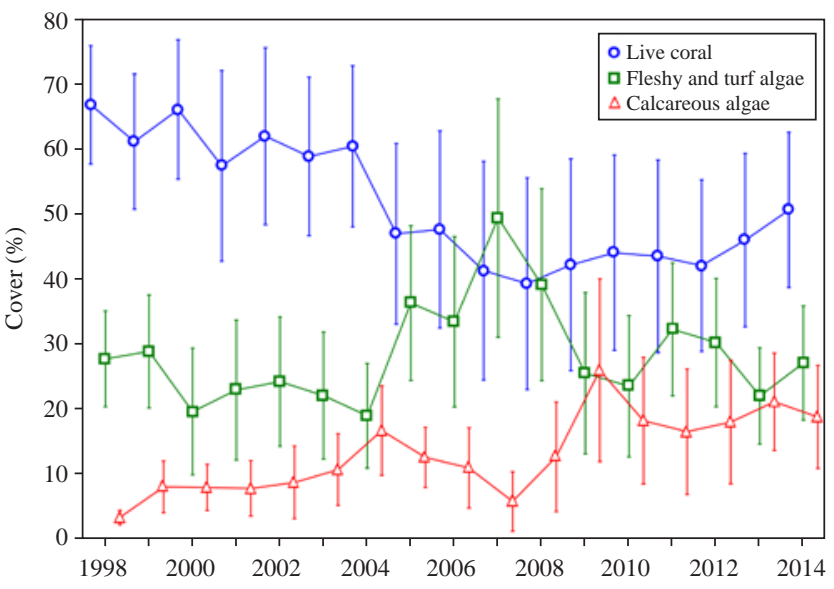

Figure 2. Temporal variation in mean ( \pm 95 \% C.I.) cover by live coral, fleshy and turf algae, and crustose coralline algae at $\mathrm{La}$ Azufrada coral reef, Gorgona Island, from 1998 to 2014. 
Table 1. Results of a linear mixed model analysis of percent cover by coral, fleshy and turf algae, and crustose coralline algae (CCA). The model included two fixed factors, Site (North and South) and Depth (shallow and deep) and a random factor (Transect) repeatedly sampled over 17 years. The model also included a variance heterogeneity term as a function of year to account for the heteroscedasticity structure within years. F tests and associated degrees of fredom (DF) and probabilities are shown for each response variable.

\begin{tabular}{lcrrrrrrr}
\hline & & \multicolumn{3}{c}{ Coral } & & \multicolumn{2}{c}{ Fleshy \& turf algae } & \multicolumn{2}{c}{ CCA } \\
\cline { 3 - 8 } Source & DF & F-value & p-value & F-value & p-value & F-value & p-value \\
\hline (Intercept) & 1,316 & 138.27 & $<0.0001$ & 114.18 & $<0.0001$ & 190.55 & $<0.0001$ \\
Site & 1,160 & 4.78 & 0.0440 & 0.35 & 0.5640 & 30.32 & $<0.0001$ \\
Depth & 1,160 & 15.99 & 0.0010 & 25.34 & 0.0001 & 19.27 & 0.0005 \\
Site x Depth & 1,160 & 0.97 & 0.3400 & 0.52 & 0.4827 & 9.80 & 0.0064 \\
Year & 1,316 & 149.17 & $<0.0001$ & 3.42 & 0.0653 & 186.46 & $<0.0001$ \\
Site x Year & 1,316 & 1.57 & 0.2113 & 12.52 & 0.0005 & 48.93 & $<0.0001$ \\
Depth x Year & 1,316 & 3.19 & 0.0752 & 2.76 & 0.0974 & 91.35 & $<0.0001$ \\
Site x Depth x Year & 1,316 & 0.00 & 0.9577 & 7.38 & 0.0070 & 41.90 & $<0.0001$ \\
\hline
\end{tabular}

from $61.0 \pm 5.7 \%$ in 1998 to $14.1 \pm 7.6 \%$ in 2008 and then increased to $40.1 \pm 7.1 \%$ in 2014 , in deep areas it tended to increase from $72.7 \pm 5.7 \%$ in 1998 to $81.5 \pm 5.7 \%$ in 2002 and then decline to $55.3 \pm 7.6 \%$ in 2012. Despite these apparently different patterns of temporal variation between depths, the year $\mathrm{x}$ depth interaction was not significant $(\mathrm{p}=$ 0.075; Table 1).

In contrast to coral cover, extent of cover by fleshy and turf algae was very heterogeneous and depended on the combination of site, depth and year (Table 1). Nonetheless, fleshy and turf algal cover combined over all depths and years did not differ significantly between sites $(27.8 \pm 3.9 \%$ vs $29.2 \pm 3.9 \%$ in the south and north, respectively). However, differences in algal cover between sites were not constant through the years and exhibited a significant site by year interaction (Table 1). In particular, algal cover was more often lower on the south than on the north site during the first half of the study, while the reverse was true for the second half of the study period. Nonetheless, both sites showed similar patterns of temporal variation with relatively lower values between 1998 - 2004, higher values between 2005 2008 and a peak in 2007, and relatively lower values again for the remaining of the study period. Fleshy and turf algal cover varied oppositely coral cover with higher values (42.3 $\pm 3.9 \%)$ in shallow than in deep areas $(14.7 \pm 3.9 \%)$. Similar to coral cover, patterns of temporal variation in algal cover tended to differ between depths, although not sufficiently for a significant year $\mathrm{x}$ depth interaction $(\mathrm{p}=0.097$; Table 1). In shallow areas, algal cover declined from $34.9 \pm 4.2 \%$ in 1998 to $24.2 \pm 5.3 \%$ in 2004 , increased to $80.9 \pm 7.0 \%$ in 2007 and then declined to $31.8 \pm 6.2 \%$ in 2014 . In contrast, in deep areas, algal cover was much more stable fluctuating between values as low as 4.0 to $4.5 \%$ in 2000, 2001 and 2010, and values as high as $23.6 \%$ in 2012.

CCA cover was also very variable spatially and temporally exhibiting a significant site $\mathrm{x}$ depth $\mathrm{x}$ year interaction (Figure 3; Table 1). Clearly, the shallow area of the north site exhibited a much more pronounced temporal variation in CCA cover than any of the other site by depth combinations. CCA cover was low in the deep plots of the two sites during all the study period, but it increased notably in shallow areas at both sites since 2008, after a decrease in fleshy and turf algae, particularly so in the north site, where CCA became the dominant component of the substrate cover.

Abundance of sea urchins and herbivorous fishes. Diadema mexicanum was the most abundant sea urchin at La Azufrada (78.1\% of all sea urchins observed during the study), followed by Centrostephanus coronatus ( 20.7\%). Other sea urchin species observed were, in decreasing order of abundance, Hesperocidaris asteriscus, Astropyga pulvinata, Toxopneustes roseus, Eucidaris thouarsii and Tripneustes depressus.

Abundance of sea urchins depended significantly on the interactions among all factors (i.e., there was a significant site $\mathrm{x}$ depth $\mathrm{x}$ year interaction; Table 2). Mean total sea urchin abundance (all sites and depths combined) varied significantly among years (Figure 4). The highest yearly mean (134.2 \pm 26.3 per $20 \mathrm{~m}^{2}$; \pm S.E.) was observed in 2002 and the lowest (35.4 \pm 7.8$)$ in 2005. Yearly means showed signs of oscillations with alternating peaks (2002, 2006, 2009, 2012, $2013)$ and troughs $(2005,2008,2011)$. Overall (all years and depths combined) total sea urchin abundance was similar between sites. However, abundance peaks observed in 2006, 2009 and 2012 were much more pronounced at the north than at the south site, particularly in the shallow area (Figure 3). Therefore, considering all years and sites combined, shallow areas had higher total sea urchin abundance than deep areas.

Only six species accounted for $96.7 \%$ of all herbivorous fishes observed during the study. These were, in decreasing order of abundance, Acanthurus xanthopterus (30.6\%), Stegastes acapulcoensis (29.1\%), Scarus ghobban (26.8\%), Acanthurus triostegus (7.4\%) and Scarus rubroviolaceus $(2.8 \%)$. Also observed were other four species with abundances $<1.2 \%$. 
Table 2. Results of three-way factorial (years x 2 sites x 2 depths) generalized linear mixed model analyses of sea urchin and herbivorous fish abundance. For the sea urchin data, transect was used as a random effects factor because the same transects were sampled repeatedly through 13 years. In contrast, the model fitted to the herbivorous fish data did not include a repeated measures structure over the 17 years of sampling. Values of the Chi-square tests and associated degrees of freedom and probabilities are shown for each response variable.

\begin{tabular}{|c|c|c|c|c|c|c|}
\hline \multirow[b]{2}{*}{ Source } & \multicolumn{3}{|c|}{ Sea urchins } & \multicolumn{3}{|c|}{ Herbivorous fish } \\
\hline & Chi-square & DF & $\mathbf{P}$ & Chi-square & DF & $\mathbf{P}$ \\
\hline Site & 0.80 & 1 & 0.3696 & 3.85 & 1 & 0.0497 \\
\hline Depth & 16.19 & 1 & $<0.0001$ & 121.15 & 1 & $<<0.0001$ \\
\hline Year & 121.07 & 12 & $<<0.0001$ & 156.43 & 16 & $<<0.0001$ \\
\hline Site x Depth & 0.13 & 1 & 0.7228 & 3.82 & 1 & 0.0507 \\
\hline Site $x$ Year & 71.15 & 12 & $<0.0001$ & 113.64 & 16 & $<<0.0001$ \\
\hline Depth x Year & 145.58 & 12 & $<<0.0001$ & 98.38 & 16 & $<<0.0001$ \\
\hline Site $\mathrm{x}$ Depth $\mathrm{x}$ Year & 50.07 & 12 & $<0.0001$ & 31.58 & 16 & 0.0113 \\
\hline
\end{tabular}
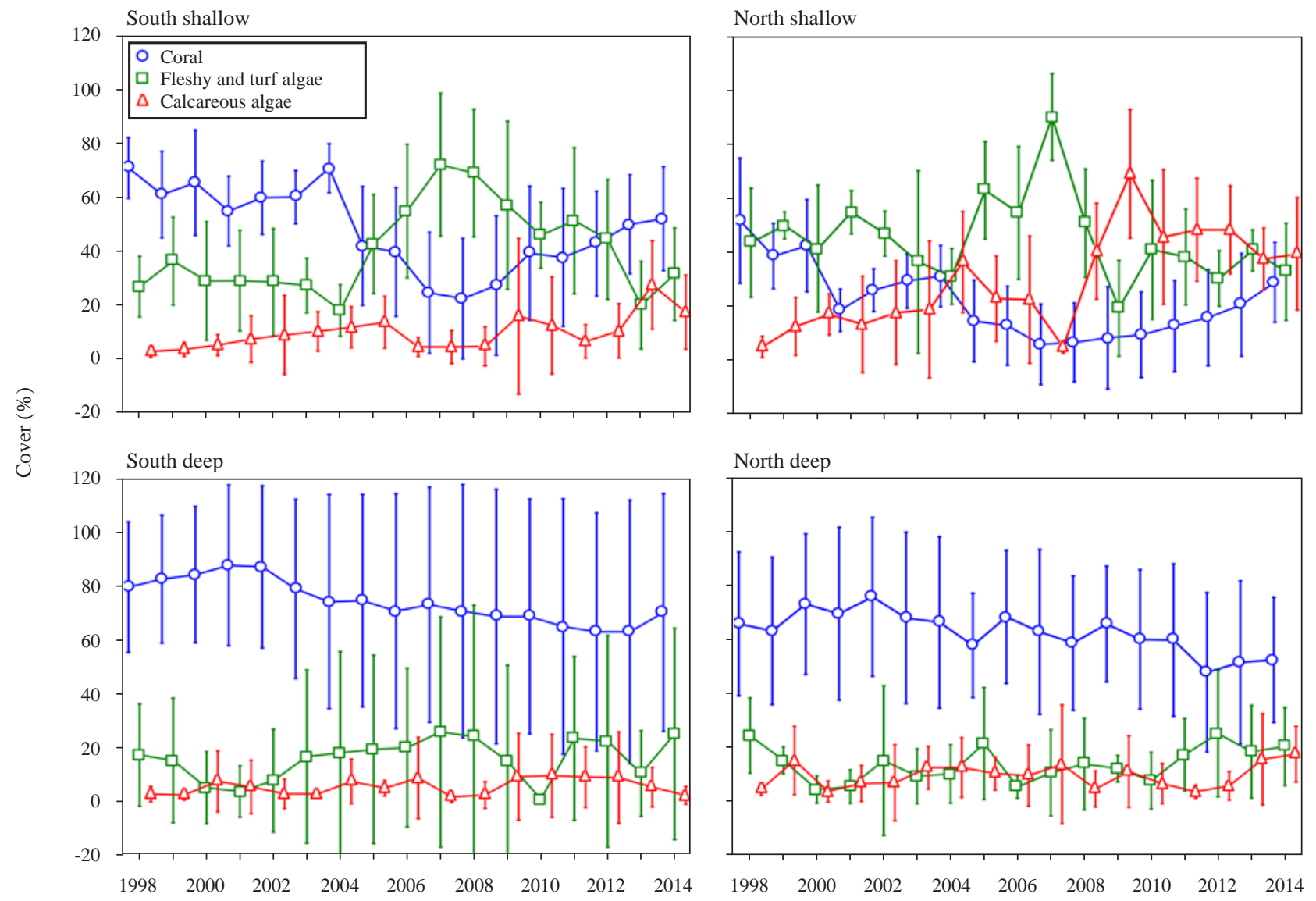

Figure 3. Temporal patterns of variation in mean ( $\pm 95 \%$ C.I.) cover by live coral, fleshy and turf algae, and crustose coralline algae at two depths (shallow and deep) within two sites (North and South) of La Azufrada coral reef during the study period.

Total abundance of herbivorous fishes varied with site, depth and year (i.e., there was a significant three-way interaction; Table 2). Considering all sites and depths combined herbivorous fish abundance varied sharply among years (Figure 5). Yearly means varied between $8.5 \pm 2.1$ fish per 60 $\mathrm{m}^{2}( \pm$ S.E.) in 2012 and $38.8 \pm 11.3$ in 2001 followed by 36.1 \pm 18.6 in 2000 . The latter two years showed clearly unusually high mean abundances and large within-year variation, particularly at the south site. Herbivorous fish abundance varied irregularly through the years although peaks and troughs did not coincide with those exhibited by sea urchins. Overall (all years and depths combined), there were only 
marginally significant differences between sites $(p=0.049)$, due to the much higher values observed in 2000 and 2001 in the south site. On average (all sites and years combined), herbivorous fish abundance was greater on shallow areas than in deep areas and this occurred particularly in 2003, 2004 and 2009 at the south site, and 2003-2004, 2008-2010 and 2013 at the north site. Clearly, herbivorous fish were more consistently abundant in the north site than in the south site (Figure 5).

\section{Discussion}

This study extends the results of a previous study (Zapata, $\boldsymbol{e t}$ al., 2010) on the benthic dynamics of La Azufrada coral reef that spanned the first seven years (1998-2004) of the period considered here. The larger duration of the current study allows a more detailed evaluation of the observed dynamics and its potential drivers in the light of hypotheses previously proposed (Zapata, et al., 2010). A major ( 27.5\%) decline in coral cover was observed over the first decade (1998-2008) of the study, causing concern that coral reefs of Gorgona Island were exhibiting a decline like that observed in many coral reefs worldwide (Gardner, et al., 2003, Bruno and Selig, 2007, De'ath, et al., 2012, Jackson, et al., 2014). However, the recovering trend observed since 2009 and the lack of major changes in environmental conditions around $\mathrm{La}$ Azufrada coral reef during the time of the study suggest that changes in coral cover are not simply the result of deteriorating conditions caused by local anthropogenic impacts.

Although coral reefs have long been known to be affected by acute natural perturbations that cause significant coral mortality (Miller, 2015), they have usually been able to recover from such perturbations within a few years (Connell, 1997; Connell, et al., 1997, 2004). However, coral reefs have also been increasingly exposed to anthropogenic, usually chronic, perturbations. Even though both natural and anthropogenic perturbations can be significant drivers of change in coral communities, the latter are increasingly becoming the dominant drivers of coral reef dynamics and appear to be responsible for the widespread decline of coral reefs (Gardner, et al., 2005; McClanahan, et al., 2008; Miller, 2015). However, because Gorgona Island is within a well-managed marine protected area, it is unlikely that the initial decline in coral cover observed in this study was caused by local, anthropogenic disturbances.

One important natural perturbation potentially responsible for the decline in coral cover observed at La Azufrada during the first decade of the study is the occurrence of El Niño warming (Glynn, et al., 2017a). While the 19821983 El Niño event was responsible for declines in coral cover of up to $85 \%$ in Eastern Tropical Pacific coral reefs (Glynn, 1990), the 1997-1998 El Niño event, which was of similar intensity and duration as the 1982-1983 event, did not cause such dramatic decline even though it negatively affected reefs in the region, including Gorgona Island's reefs (Vargas-Angel, et al., 2001). Levels of coral mortality during the 1997-1998 El Niño were $5 \%$ at Caño Island,

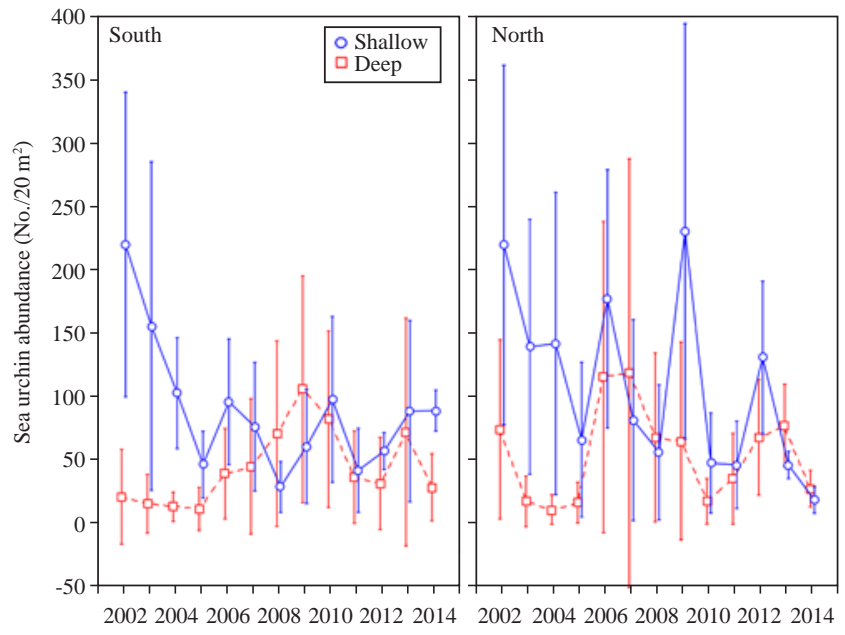

Figure 4. Temporal patterns of variation in mean ( $\pm 95 \%$ C.I.) sea urchin abundance at two depths (shallow and deep) within two sites (North and South) of La Azufrada coral reef between 2002 and 2014.

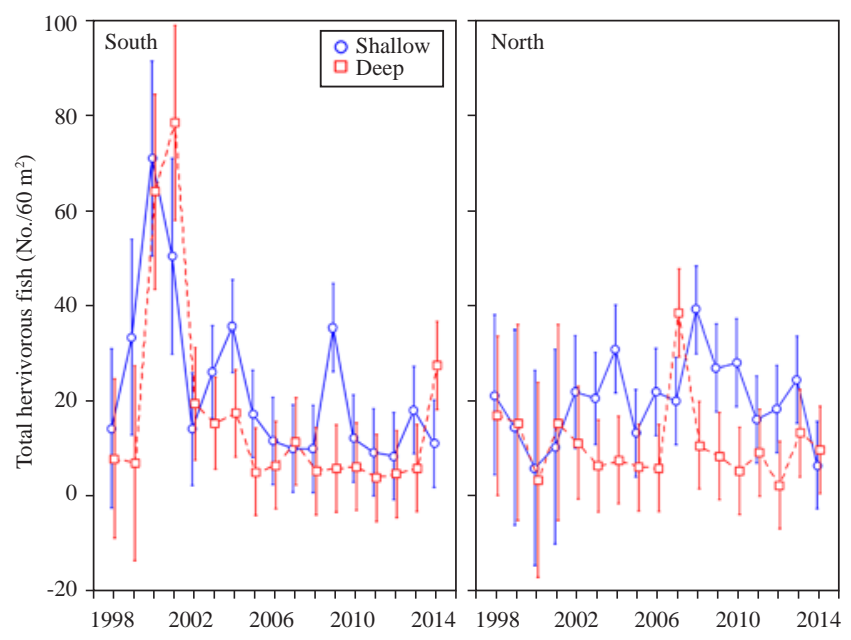

Figure 5. Temporal patterns of variation in mean ( $\pm 95 \%$ C.I.) abundance of herbivorous fishes at two depths (shallow and deep) within two sites (North and South) of La Azufrada coral reef between 1998 and 2014.

Costa Rica (Guzmán and Cortés, 2001), 7 \% on mainland Ecuador and $13 \%$ in the Gulf of Chiriquí, Panama (Glynn, et al., 2001). Levels of bleaching reported for La Azufrada were at most $32 \%$ of live coral cover on the reef slope at the peak of this event but coral mortality was low $(<1 \%$; Vargas-Angel, et al., 2001). Even though the 1997-1998 El Niño event might explain the $6 \%$ decline in coral cover observed from 1998 to 1999, no other major El Niño events occurred during the study period that could help explain the decline in coral cover observed until 2008. I conclude, therefore, that El Niño warming events are not a significant driving force explaining the dynamics of coral and algal cover at La Azufrada reef during the study period. 
Major differences in the benthic dynamics of shallow and deep areas observed in this as well as in the previous study by Zapata, et al. (2010) help reveal a major driver of benthic dynamics at La Azufrada reef. Clearly, the magnitude of fluctuations in coral and algal cover were much greater in shallow than in deep areas of the reef. Furthermore, patterns of temporal variation in benthic cover were similar between the two study sites, indicating the occurrence of a phenomenon at a sufficiently large spatial scale to encompass the two sites separated by $\sim 400 \mathrm{~m}$. One major, recurrent natural perturbation affecting coral reefs at Gorgona Island and capable of differentially affecting shallow and deep areas of reefs is the subaerial exposure of corals during extreme low tides (Zapata, et al., 2001; Zapata and Vargas-Ángel, 2003). This phenomenon occurs every few years at Gorgona Island as it does elsewhere in the ETP (Glynn, 1976; Eakin and Glynn, 1996; Cortés and Jiménez, 2003; Maté, 2003; Glynn, et al., 2017a) and explains much of the differences observed in the dynamics of coral and algal cover between depths. Estimates made at La Azufrada reef indicate that subaerial exposure of corals occurs at tide levels below $\sim-0.4 \mathrm{~m}$ relative to the $0.0 \mathrm{~m}$ tide table datum (IDEAM, 2000). Because the lowest astronomical tides can reach down to $-0.7 \mathrm{~m}$ relative to the tidal datum, large areas of the shallowest portions of the reef crest and reef flat can be exposed to air, whereas deeper areas are not affected by this phenomenon (Figure 6A,B). While short-time (15 - 40 min) subaerial exposure of corals can reduce zooxhanthellae density and fecundity in Pocillopora damicornis (CastrillónCifuentes, et al., 2017), prolonged ( $>1 \mathrm{~h}$ ) subaerial exposure occurring at mid-day or coinciding with unfavorable weather conditions (e.g., intense solar radiation or heavy rain, Maté, 2003) and occurring repeatedly during several consecutive days can cause severe coral bleaching (Figure 6C) and mortality (Glynn, 1976; Zapata and Vargas-Ángel, 2003; Glynn, et al., 2017a). Once dead, the colonies are quickly colonized by filamentous algae. Often, only the most distal tips of branches are subaerially exposed in some colonies, and subsequently only those affected portions bleach and die, while the remaining unexposed, lower portions of colonies maintain healthy tissues (Figure 6D). Nonetheless, the dead tips of branches are also colonized by algae, which, after growing for a few weeks, form a thick algal mat that overgrows and kills the remaining tissue, most likely by preventing light penetration. This process creates algal patches of varying sizes on the most elevated portions of the reef (Figure 6D-F). Thus, generally the effect of aerial tidal emersion is a decrease in coral cover and a concomitant increase in algal cover on shallow areas. In contrast, deep areas of the reef are never subaerially exposed during extreme low tides and therefore exhibit much less amongyear variation in coral and algal cover.

While extreme low-tide subaerial exposure of corals explains most of the decreases in live coral and increases in algal cover observed in shallow areas of the reef until
2008, what explains the recovery of live coral and decline in algal cover observed after 2008? For any recovery to occur, a process of succession must ensue after perturbation (Connell and Slatyer, 1977; Doropoulos, et al., 2016). I suggest that once algae become abundant after coral death following subaerial exposures, herbivores play a crucial, facilitating role in the recovery process by exerting two important effects: first, they remove the algae from dead coral substrates, and second, they erode the reef substrate and therefore increase its depth making it less likely to be subaerially exposed during a subsequent extreme low tide. Evidence for this idea is provided by the fact that on average, sea urchins and herbivorous fish are more abundant in shallow than in deep areas. Although clearly highly dynamic and variable, at both sites the abundance of sea urchins and herbivorous fish was greater in shallow than in deep areas of the reef most of the years. Once herbivores remove the fleshy and turf algae, crustose coralline algae growing on coral rubble become dominant, and later a hard-calcareous pavement is formed as result of cementation by the encrusting calcareous algae. These crustose coralline algae are known to induce coral larval settlement and affect post-settlement survival generally facilitating coral recruitment (Heyward and Negri, 1999, Harrington, et al., 2004).

Three mechanisms of recovery of live coral cover can occur: 1) Sublethal effects of subaerial exposure on corals are frequently observed even after major mortality has occurred throughout the reef flat and crest. Small surviving portions of colonies act as effective juvenile coral colonies that can grow back (Glynn and Fong, 2006). 2) Settlement of sexually produced larvae and their subsequent juvenile recruitment also contribute to repopulate affected areas of the reef. While it has been difficult to observe coral larval settlement on artificial substrates in the eastern tropical Pacific (Medina-Rosas, et al., 2005; López-Pérez, et al., 2007), including Gorgona Island (Lozano-Cortés and Zapata, 2014), histological evidence clearly indicates that gonad maturation and sexual reproduction indeed occur in ETP coral populations (Glynn, et al., 2017b), including those at La Azufrada reef (Castrillón-Cifuentes, et al., 2015). In fact, juvenile colonies are often seen on the bare carbonate pavement on the reef flat of La Azufrada reef suggesting that recruitment of sexually-produced colonies is occurring (Jaramillo-González, 2012). However, it is not known whether coral populations at Gorgona Island are self-replenishing or are open. Given its negative effects on coral fecundity and zooxanthellae density at Gorgona Island (Castrillón-Cifuentes, et al., 2017), subaerial exposure could affect coral reproduction and subsequent settlement and recruitment success. 3) Recruitment of new colonies produced by the fragmentation of adult colonies. It has been long-known that fragmentation is an important and common mechanism of asexual reproduction in eastern tropical Pacific coral reefs (Highsmith, 1982; Glynn, et al., 2017b). In fact, several mechanisms causing coral fragmentation of 

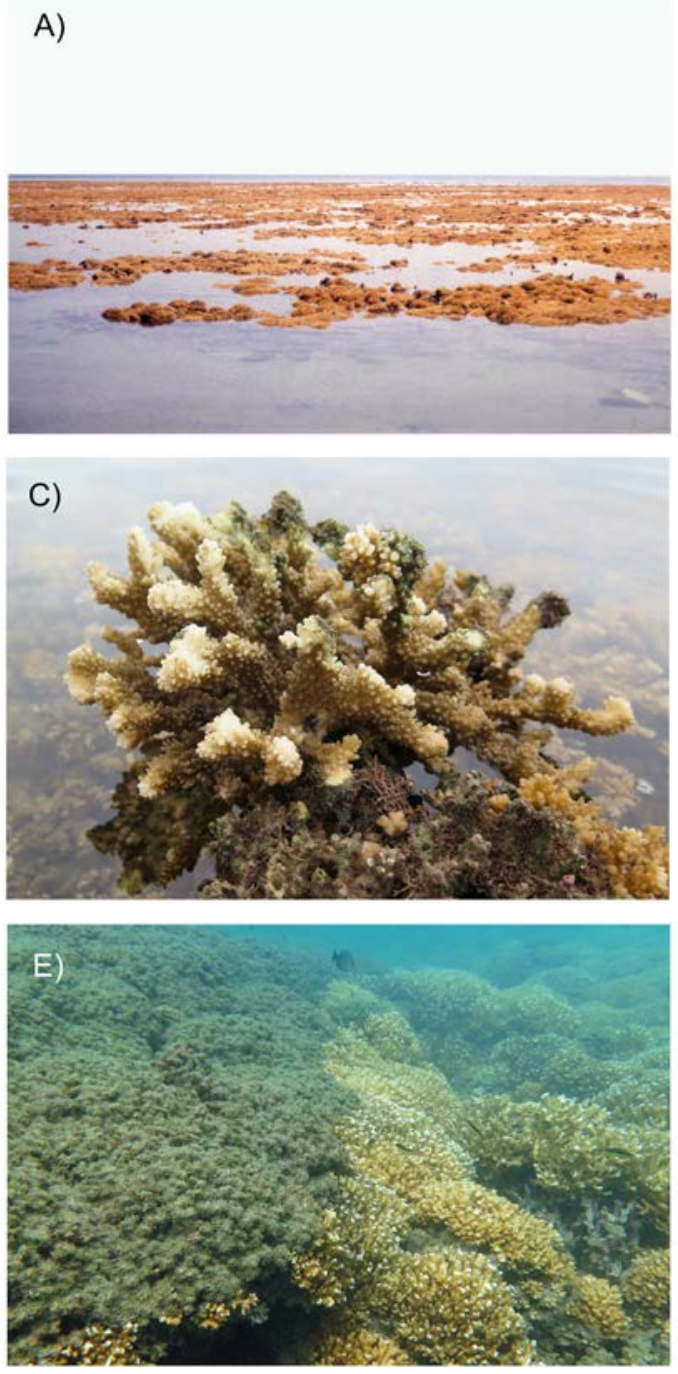
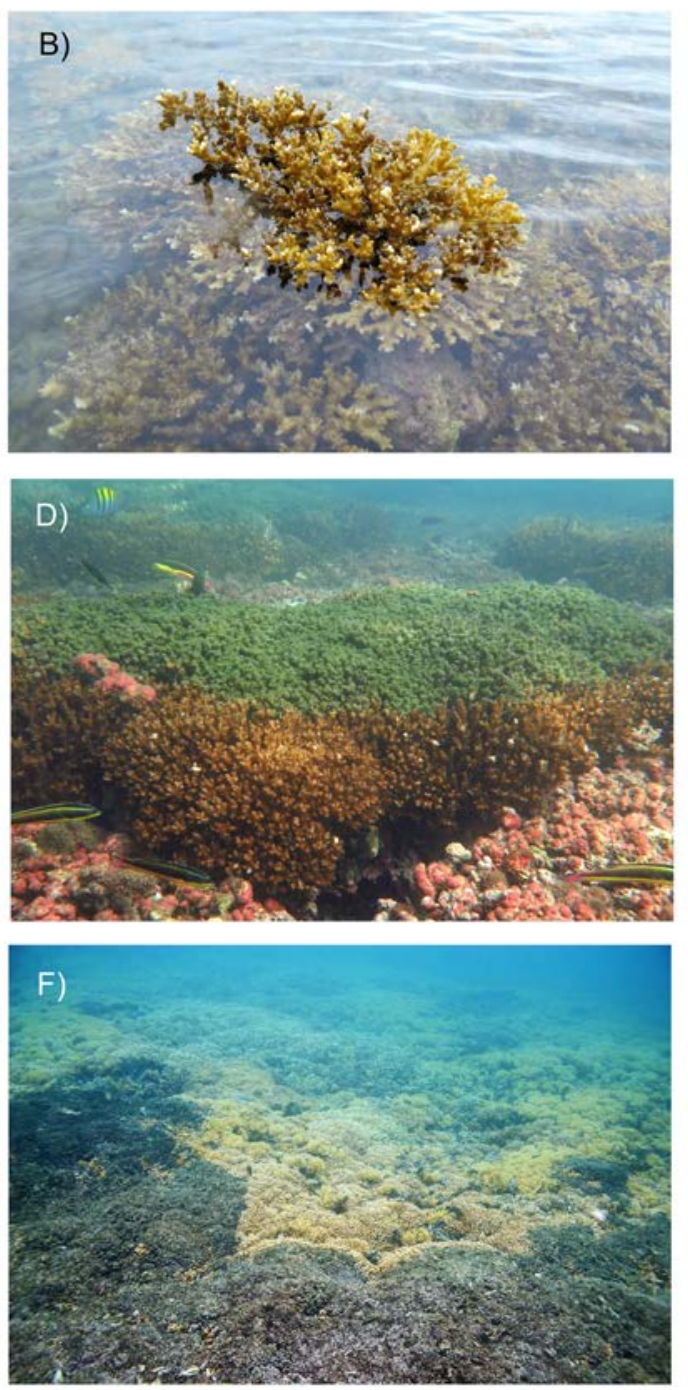

Figure 6. Effects of extreme low tidal subaerial exposure of coral reefs at Gorgona Island, Colombian Pacific Ocean. A) Extensive subaerial exposure of La Azufrada coral reef. B) Recently exposed coral colony showing healthy tissue. C) Partially bleached coral colony during a subaerial exposure event. D) Cluster of coral colonies with upper portion covered by filamentous algae a few weeks after subaerial exposure. E) and F) Contrast between shallow areas of the reef extensively covered by filamentous algae as consequence of a subaerial exposure event (dark areas on left or lower portions of photographs) and healthy coral (pale yellow-khaki color on the right) in adjacent deeper areas not subaerially exposed.

pocilloporid colonies have been documented on Gorgona Island coral reefs, including fish predation (Guzmán and López, 1991; Palacios, et al., 2014; Enochs and Glynn, 2017) and breakage of colonies by drifting logs (Muñoz, et al., 2015). Fragments produced often survive and grow successfully and significantly contribute to the recovery of areas affected by subaerial exposures. Because shallow areas of the reef are overwhelmingly dominated by branching (pocilloporid) corals, fragmentation is a major, perhaps the most important, coral recovery mechanism at La Azufrada reef. Paradoxically, once the coral cover is recovered, the reef starts to build up until it reaches a point in which it again becomes vulnerable to subaerial exposure starting a new cycle of disturbance and recovery.

\section{Conclusions}

This study suggests that La Azufrada coral reef exhibits cyclic dynamics that are the result of the interplay between a physical disturbance (subaerial exposure during extreme low tides) and biological processes. The latter include two interspecific interactions: herbivory, which plays a vital role at the beginning of the process of succession after disturbance, and corallivory, which is responsible for much coral asexual reproduction by fragmentation and enhances the recovery of coral cover. Other biological processes are coral sexual reproduction, recruitment, and subsequent coral growth. Although the evidence presented here is strongly suggestive, the 17-year-long time series considered in this paper is still too short to demonstrate a complete cycle of 
disturbance and recovery at la Azufrada reef; however, it indicates that the period of such cycle, if it indeed occurs, is in the order of decades. The view that coral reef benthic dynamics are driven by disturbance-recovery cycles dates to the work of Connell (1978) and there is good evidence that in the absence of anthropogenic disturbances coral reefs recover from acute natural disturbances (Connell, 1997; Connell, et al., 1997, 2004; Miller, 2015). This study strongly suggests that such is the case at La Azufrada reef and other coral reefs of Gorgona Island because they are exempt from the local environmental insults that many other reefs worldwide are exposed to. Currently, there is much debate regarding whether coral reef decline worldwide is due to global climate change or to local anthropogenic impacts (Knowlton and Jackson, 2008; Kennedy, et al., 2013), and the case of La Azufrada reef suggests that if local human impacts are low, ecosystem resilience to natural perturbations will not be compromised. However, there is increasing concern that anthropogenic global change will increase the frequency and intensity of natural perturbations such as El Niño warming and bleaching events, and ocean acidification (Eakin, et al., 2009; Hoey, et al., 2016), both of which will reduce coral reef resilience in the eastern tropical Pacific.

\section{Acknowledgments}

While I am responsible for all data analyses and interpretation, this work could not have been possible without the contribution of many people and institutions. Foremost among people, I thank J. Garzón-Ferreira for realizing his vision of creating a National Monitoring System for the Coral Reefs of Colombia (SIMAC) and A. RodríguezRamírez and R. Navas-Camacho for continuing his work until 2013. Second, numerous people have helped with data collection and organization through the years; for this I thank C. Muñoz, D. Lozano, M. Rodríguez, M. López, A. Alzate, J. Jaramillo, M. Palacios, A. Palacio, A. Castrillón, I. Lemos, S. Bejarano, N. Bernal, J. Daza, E. Flórez, J. García, D. Gil, C. Gómez, D. Gómez, P. Herrón, V. Izquierdo, L. Lizcano, S. Lozano, T. Llanes, M. Maya, A. Mejía, K. Mejía, S. Ramírez, J. Pinzón, M. Reyes-Nivia, J. Rojas, J. Tavera, A. Tobón, J. Vega and V. Zambrano. Colombian National Natural Parks personnel at Gorgona Island, particularly C. Acevedo, C. Gómez, G. Mayor, L. Chasqui, N. Murillo, L. Payán, and especially X. Zorrilla have decisively supported this project. I am very grateful to W. Torres for his help and advice with statistical analyses and to A. Caicedo for help with data management, figures and references. Financial support was provided by Institute for Marine and Coastal Research (INVEMAR), the Colombian Administrative Department of Science, Technology and Innovation (COLCIENCIAS; grant 2105-09-327-97, the Regional Coordination Unit for the Caribbean of the United Nations Environment Program (UNEP- CAR/RCU), the National Environmental Fund (FONAM) through Environmental Program Agreement BID-
$7740 \mathrm{C} / \mathrm{CO}$, Conservation International, WWF Colombia, National Natural Parks of Colombia, and the Coral Reef Ecology Research Group of Universidad del Valle. I thank A. Salinas, P. Montoya, H. Botero, J. Velez and Aviatur for logistic support. Finally, I thank two anonymous reviewers whose comments helped improve this paper.

\section{Conflic of interest}

The author declares no conflict of interests.

\section{References}

Aronson, R. B. \& Precht, W. F. (1997). Stasis, biological disturbance, and community structure of a Holocene coral reef. Paleobiology. 23: 326-346.

Aronson, R. B., Precht, W. F. Toscano, M. A. \& Koltes, K. H. (2002). The 1998 bleaching event and its aftermath on a coral reef in Belize. Marine Biology. 141: 435-447.

Baker, A. C., Glynn, P. W. \& Riegl, B. (2008). Climate change and coral reef bleaching: An ecological assessment of longterm impacts, recovery trends and future outlook. Estuarine, coastal and shelf science. 80 (4): 435-471.

Bastidas-Salamanca, M., Rangel-Buitrago, N., Morales-Giraldo, D., Ricaurte, C., Gómez-López, D. I., Navas-Camacho, R., Navarrete, S. M., Alonso, D. A., Lizbeth, C., VivasAguas, J., Obando-Madera, P. S., Rodríguez-Rodríguez. J. A., Victoria-Licero, L., Villanueva, L. \& Perdomo, V. (2014). Estado del ambiente y de los ecosistemas marinos y costeros. In: INVEMAR. Informe del estado de los ambientes y recursos marinos y costeros en Colombia: Año 2013. (p. 23-82). Santa Marta, Colombia: INVEMAR, Serie de Publicaciones Periódicas No. 3.

Bates, D., Maechler, M., Bolker, B. \& Walker, S. (2015). Fitting Linear Mixed-Effects Models Using lme4. Journal of Statistical Software. 67 (1): 1-48.

Birkeland, C. (1997). Life and death of coral reefs. New York, USA: Chapman \& Hall

Birrell, C. L., McCook, L. J., Willis, B. L. \& Díaz-Pulido, G. A. (2008). Effects of benthic algae on the replenishment of corals and the implications for the resilience of coral reefs. Oceanography and Marine Biology: An Annual Review. 46: 25-63.

Blanco, J. F. (2009). The hydroclimatology of Gorgona Island: Seasonal and ENSO-related patterns. Actualidades Biológicas. 31 (91): 111-121.

Brown, B. E. (1997a). Disturbances to reefs in recent times. In C. Birkeland (ed.), Life and death of coral reefs (p. 354-379). New York, USA: Chapman \& Hall.

Brown, B. E. (1997b). Coral bleaching: causes and consequences. Proceedings of the $8^{\text {th }}$ International Coral Reef Symposium. 1: 65-74.

Bruno, J. F. \& Selig, E. R. (2007). Regional decline of coral cover in the Indo-Pacific: timing, extent, and subregional comparisons. PLoS one. 2 (8): e711.

Bryant, D., Burke, L., McManus, J. \& Spalding, M. (1998). Reefs at risk: a map-based indicator of threats to the world's coral reefs. Washington D. C., USA: World Resources Institute.

Buddemeier, R. W., Kleypas, J. A. \& Aronson, R. B. (2004). Coral reefs and climate change. Potential contribution of climate change to stresses coral reef ecosystems. Arlington, Virginia, USA: Pew Center on Global Climate Change. 
CARICOMP. (2001). CARICOMP Methods manual, levels 1 and 2: Manual of methods for mapping and monitoring of physical and biological parameters in the coastal zone of the Caribbean. Kingston, Jamaica: CARICOMP Data Management Center, University of the West Indies.

Carpenter, R. C. (1990). Mass mortality of Diadema antillarum. I. Long-term effects on sea urchin population dynamics and coral reef algal communities. Marine Biology. 104: 67-77.

Castrillón-Cifuentes, A. L., Lozano-Cortés, D. F. \& Zapata, F. A. (2017). Effect of short-term subaerial exposure on the cauliflower coral, Pocillopora damicornis, during a simulated extreme low-tide event. Coral Reefs. 1-14.

Castrillón-Cifuentes, A. L., Muñoz, C. G. \& Zapata, F. A. (2015). Reproductive patterns of the coral Pocillopora damicornis at Gorgona Island, Colombian Pacific Ocean. Marine Biology Research. 11 (10): 1065-1075.

Connell, J. H. \& Slatyer, R. O. (1977). Mechanisms of succession in natural communities and their role in community stability and organization. The American Naturalist. 111 (982): 1119-1144.

Connell, J. H. (1978). Diversity in tropical rain forests and coral reefs. Science. 199: 1302-1310.

Connell, J. H. (1997). Disturbance and recovery of coral assemblages. Coral Reefs. 16 Suppl.: S101-S113.

Connell, J. H., Hughes, T. P. \& Wallace, C. C. (1997). A 30-year study of coral abundance, recruitment, and disturbance at several scales in space and time. Ecological Monographs. 67: 461-488.

Connell, J. H., Hughes, T. P., Wallace, C. C., Tanner, J. E., Harms, K. E. \& Kerr, A. M. (2004). A long-term study of competition and diversity of corals. Ecological Monographs. 74: $179-210$.

Cortés, J. \& Jiménez, C. (2003). Corals and coral reefs of the Pacific of Costa Rica: history, research and status. In J. Cortés (ed.), Latin America coral reefs (p. 361-385). Amsterdam, The Netherlands: Elsevier Science B. V.

De'ath, G., Fabricius, K. E., Sweatman, H. \& Puotinen, M. (2012). The 27-year decline of coral cover on the Great Barrier Reef and its causes. Proceedings of the National Academy of Sciences. 109 (44): 17995-17999.

Devis-Morales, A., García-Hansen, I., Malikov, I. \& VillegasBolaños, N. L. (2002). Compilación oceanográfica de la cuenca Pacífica colombiana. Serie Publicaciones Especiales Vol. 1, Tumaco, Colombia. Centro Control Contaminación del Pacífico (CCCP).

Díaz, J. M., Barrios, L. M., Cendales, M. H., Garzón-Ferreira, J., Geister, J., López-Victoria, M., Ospina, G. H., ParraVelandia, F., Pinzón, J., Vargas-Ángel, B., Zapata, F. A \& Zea, S. (2000). Áreas coralinas de Colombia. Santa Marta, Colombia: INVEMAR, Serie de Publicaciones Especiales 5.

Díaz, J. M., Díaz-Pulido, G., Garzón-Ferreira, J., Geister, J., Sánchez, J. \& Zea, S. (1996). Atlas de los arrecifes coralinos del Caribe colombiano. Complejos arrecifales oceánicos. Santa Marta, Colombia: INVEMAR, Serie de Publicaciones Especiales 2.

Díaz, J. M., Garzón-Ferreira, J. \& Zea, S. (1995). Los arrecifes coralinos de la Isla de San Andrés, Colombia: Estado actual y perspectivas para su conservación. Bogotá, Colombia: Academia Colombiana de Ciencias Exactas Físicas y Naturales. Colección Jorge Álvarez Lleras 7.
Díaz, J. M., Pinzón, J. H, Perdomo, A. M., Barrios, L. M. \& López-Victoria, M. (2001). Generalidades. In L.M. Barrios \& M. López-Victoria (eds.), Gorgona Marina: Contribución al conocimiento de una isla única (p. 1726). Santa Marta, Colombia: INVEMAR, Serie de Publicaciones Especiales 7.

Doropoulos, C., Roff, G., Visser, M. S. \& Mumby, P. J. (2016). Sensitivity of coral recruitment to subtle shifts in early community succession. Ecology. 98 (2): 304-314.

Eakin, C. M. \& Glynn, P. W. (1996). Low tidal exposures and reef mortalities in the eastern Pacific. Coral Reefs. 15: 120.

Eakin, C. M., Lough, J. M., Heron, S. F. (2009). Climate variability and change: monitoring data and evidence for increased coral bleaching stress. In: M. J. H. van Oppen \& J. M. Lough (eds.), Coral Bleaching: Patterns, processes, causes and consequences (p. 41-67). Berlin, Germany: Ecological Studies 205, Springer-Verlag.

Enfield, D. B. (2001). Evolution and historical perspective of the 1997-1998 El Niño-Southern Oscillation event. Bulletin of Marine Science. 69: 7-25.

Enochs, I. C. \& Glynn, P. W. (2017). Corallivory in the Eastern Pacific. In: P. W. Glynn, D. P. Manzello \& I. C. Enochs (eds.), Coral Reefs of the Eastern Tropical Pacific: Persistence and loss in a dynamic environment (p. 315337). Dordrecht, The Netherlands: Springer.

Fabricius, K. E. (2005). Effects of terrestrial runoff on the ecology of corals and coral reefs: review and synthesis. Marine Pollution Bulletin. 50: 125-146

Gardner, T. A., Côté, I. M., Gill, J. A., Grant, A. \& Watkinson, A. R. (2003). Long-term region-wide declines in Caribbean corals. Science. 301: 958-960.

Gardner, T. A., Côté, I. M., Gill, J. A., Grant, A. \& Watkinson, A. R. (2005). Hurricanes and Caribbean coral reefs: impacts, recovery patterns, and role in long-term decline. Ecology. 86: 174-184.

Garzón-Ferreira, J. \& Kielman, M. (1994). Extensive mortality of corals in the Colombian Caribbean during the last two decades. In R. N. Ginsburg (ed.), Proceedings of the Colloquium on Global Aspects of Coral Reefs. Health, Hazards and History (p. 247-253). Miami, USA: RSMAS, University of Miami.

Garzón-Ferreira, J. \& Rodríguez-Ramírez, A. (2010). SIMAC: Development and implementation of a coral reef monitoring network in Colombia. Revista de Biología Tropical. 58: $67-80$.

Garzón-Ferreira, J. (1997). Arrecifes Coralinos: ¿Un tesoro camino a la extinción? Colombia: Ciencia y Tecnología. 15: 11-19.

Garzón-Ferreira, J., Cortes, J., Croquer, A., Guzmán, H., Leao, Z. \& Rodríguez-Ramírez, A. (2002a). Status of coral reefs in southern tropical America in 2000-2002: Brazil, Colombia, Costa Rica, Panama and Venezuela. In C. Wilkinson (ed.), Status of coral reefs of the World: 2002 (p. 343-360). Townsville, Australia: Australian Institute of Marine Science (AIMS).

Giraldo, A., Rodríguez-Rubio, E. \& Zapata, F. A. (2008). Condiciones oceanográficas en Isla Gorgona, Pacífico oriental tropical de Colombia. Latin American Journal of Aquatic Research. 36: 121-128.

Gladfelter, W. B. (1982). White band disease in Acropora palmata: Implication for the structure and growth of shallow reefs. Bulletin of Marine Science. 32: 639-643. 
Glynn, P. W. (1976). Some physical and biological determinants of coral community structure in the eastern Pacific. Ecological Monographs. 46: 431-456.

Glynn, P. W. (1990). Coral mortality and disturbances to coral reefs in the tropical eastern Pacific. In P. W. Glynn (ed.), Global ecological consequences of the 1982-83 El Niño-Southern Oscillation (p. 55-126). Amsterdam, The Netherlands: Elsevier.

Glynn, P. W. (1993). Coral reef bleaching: ecological perspectives. Coral Reefs. 12: 1-17.

Glynn, P. W., Colley, S. B., Carpizo-Ituarte, E. \& Richmond, R. H. (2017b). Coral Reproduction in the Eastern Pacific. In: P. W. Glynn, D. P. Manzello \& I. C. Enochs (eds.), Coral Reefs of the Eastern Tropical Pacific: Persistence and loss in a dynamic environment (p. 435-476). Dordrecht, The Netherlands: Springer.

Glynn, P. W., Cortés-Núñez, J., Guzmán-Espinal, H. M. \& Richmond, R. H. (1988). El Niño (1982-83) associated coral mortality and relationship to sea surface temperature deviations in the tropical eastern Pacific. Proceedings of the $6^{\text {th }}$ International Coral Reef Symposium. 3: 237-243.

Glynn, P. W., Fong, P. (2006). Patterns of reef coral recovery by the regrowth of surviving tissues following the $1997-98$ El Niño warming and 2000, 2001 upwelling cool events in Panama, eastern Pacific. Proceedings of $10^{\text {th }}$ International Coral Reef Symposium. 624-630.

Glynn, P. W., Maté, J. L., Baker, A. C. \& Calderón, M. (2001). Coral Bleaching and mortality in Panama and Ecuador during the 1997-1998 El Niño- Southern oscillation event: Spatial and temporal patterns and comparisons with the 1982-1983 event. Bulletin of Marine Science. 69: 79-109.

Glynn, P. W., Mones, A. B., Podestá, G. P. Colbert, A. \& Colgan, M. W. (2017a). El Niño-Southern Oscillation: Effects on Eastern Pacific coral reefs and associated biota. In P. W. Glynn, D. P. Manzello \& I. C. Enochs (eds.), Coral Reefs of the Eastern Tropical Pacific: Persistence and loss in a dynamic environment (p. 251-290). Dordrecht, The Netherlands: Springer.

Glynn, P. W., Prahl, H. von. \& Guhl, F. (1982). Coral reef of Gorgona Island, Colombia, with special reference to corallivores and the influence on community structural reef development. Anales del Instituto de Investigaciones Marinas de Punta Betín. 12: 185-214.

Grassle, J. F. (1973). Variety in coral reef communities. In O. A. Jones \& R. Endean (eds.), Biology and geology of coral reefs, Vol. 2 (p. 247-270). New York, USA: Academic Press.

Guzmán, H. M. \& Cortés, J. (2001). Changes in reef community structure after fifteen years of natural disturbances in the eastern Pacific (Costa Rica). Bulletin of Marine Science. 69: 133-149.

Guzmán, H. M., López, J.D. (1991). Diet of the corallivorous pufferfish Arothon meleagris (Pisces: Tetraodontidae) at Gorgona Island, Colombia. Revista de Biología Tropical. 39: 203-206.

Harrington, L., Fabricius, K., De’Ath, G. \& Negri, A. (2004). Recognition and selection of settlement substrata determine post-settlement survival in corals. Ecology. 85 (12): 34283437.

Harvell, C. D., Mitchell, C. E, Ward, J. R., Altizer, S., Dobson, A. P., Ostfeld, R. S. \& Samuel, M. D. (2002). Climate warming and disease risks for terrestrial and marine biota. Science. 296: 2158-2162.
Heyward, A. J. \& Negri, A. P. (1999). Natural inducers for coral larval metamorphosis. Coral reefs. 18 (3): 273-279.

Highsmith, R. C. (1982). Reproduction by fragmentation in corals. Marine Ecology Progress Series. 7 (2): 207-226.

Hoegh-Guldberg, O., Mumby, P. J., Hooten, A. J., Steneck, R. S., Greenfield, P., Gómez, E., Harvell, C. D., Sale, P. F., Edwards, A. J., Caldeira, K., Knowlton, N., Eakin, C. M., Iglesias-Prieto, R., Muthiga, N., Bradbury, R. H., Dubi, A., \& Hatziolos, M. E. (2007). Coral reefs under rapid climate change and ocean acidification. Science. 318 (5857): 1737-1742.

Hoey, A. S., Howells, E., Johansen, J. L., Hobbs, J. P. A., Messmer, V., McCowan, D. M., Wilson, S. K. \& Pratchett, M. S. (2016). Recent advances in understanding the effects of climate change on coral reefs. Diversity. 8 (2): 12.

Hughes, T. P. (1994). Catastrophes, phase shifts, and large-scale degradation of a Caribbean coral reef. Science. 265: 15471551.

Hughes, T. P., Baird, A. H., Bellwood, D. R., Card, M, Connolly, S. R., Folke, C., Grosberg, R., Hoegh-Guldberg, O., Jackson, J. B. C., Kleypas, J., Lough, J. M., Marshall, P., Nyström, M., Palumbi, S. R., Pandolfi, J. M., Rosen, B. \& Roughgarden, J. (2003). Climate change, human impacts, and the resilience of coral reefs. Science. 301: 929-933.

IDEAM. (2000). Pronóstico de pleamares y bajamares en la costa pacífica colombiana año 2001. Bogotá, Colombia: Instituto de Hidrología, Meteorología y Estudios Ambientales (IDEAM).

Jackson, J. B. C., Donovan, M. K., Cramer, K. L., Lam, V. V. (2014). Status and trends of caribbean coral reefs: 1970 2012. Gland, Switzerland: Global Coral Reef Monitoring Network, IUCN.

Jackson, J. B. C., Kirby, M. X., Berger, W. H., Bjorndal, K. A., Botsford, L. W., Bourque, B. J., Bradbury, R. H., Cooke. R., Erlandson, J., Estes, J. A., Hughes, T. P., Kidwell, S., Lange, C. B., Lenihan, H. S., Pandolfi, J. M., Peterson, C. H., Steneck, R. S., Tegner, M. J. \& Warner, R. R. (2001). Historical overfishing and the recent collapse of coastal ecosystems. Science. 293: 629-638.

Jaramillo-González, J. (2012). Variación espacial y temporal del reclutamiento coralino en dos arrecifes del Parque Nacional Natural Gorgona (Pacífico Colombiano). Tesis de Maestría, Departamento de Biología, Universidad del Valle, Cali.

Jennings, S. \& Polunin, N. (1996). Impacts of fishing on tropical ecosystems. Ambio. 25: 44-49.

Kennedy, E. V., Perry, C. T., Halloran, P. R., Iglesias-Prieto, R., Schönberg, C. H., Wisshak, M., Form, A. U., CarricartGanivet, J. P., Fine, M., Eakin, C. M. \& Mumby, P. J. (2013). Avoiding coral reef functional collapse requires local and global action. Current Biology. 23 (10): 912-918.

Kleypas, J. A., McManus, J. W. \& Meñez, L. A. (1999). Environmental limits to coral reef development: where do we draw the line? American Zoologist. 146-159.

Knowlton, N., Jackson, J. B. C. (2008). Shifting baselines, local impacts, and global change on coral reefs. PLoS Biol 6 (2): e54.

Lessios, H. A., Robertson, D. R. \& Cubit, J. D. (1984). Spread of Diadema mass mortality through the Caribbean. Science. 226: 335-337.

Liddell, W. D. \& Ohlhorst, S. L. (1992). Ten years of disturbance and change on a Jamaican fringing reef. Proceeding of the $7^{\text {th }}$ International Coral Reef Symposium. 1: 144-150. 
López-Pérez, R. A., Mora-Pérez, M. G. \& Leyte-Morales, G. E. (2007). Coral (Anthozoa: Scleractinia) recruitment at Bahías de Huatulco, Western México: Implications for coral community structure and dynamics 1 . Pacific Science. 61 (3): 355-369.

Loya, Y. (1978). Plotless and transect methods. In D. R. Stoddart \& R. F. Johannes (eds.), Coral reefs: research methods (p. 197217). Norwich, England: Monographs on oceanographic research 39 (5). UNESCO.

Lozano-Cortés, D. F., \& Zapata, F. A. (2014). Invertebrate colonization on artificial substrates in a coral reef at Gorgona Island, Colombian Pacific Ocean. Revista de Biología Tropical. 62: 161-168.

Maté, J. L. (2003). Corals and coral reefs of the Pacific coast of Panamá. In J. Cortés (ed.), Latin America coral reefs (p. 387417). Amsterdam, The Netherlands: Elsevier Science B.V.

McClanahan, T. R., Buddemeier, R. W., Hoegh-Guldberg, O. \& Sammarco, P. (2008). Projecting the current trajectory for coral reefs. In N. V. C., Polunin (ed.). Aquatic Ecosystems (p. 242-262). Cambridge, UK: Cambridge University Press.

McWilliams, J. P., Côté, I. M., Gill, J. A., Sutherland, W. J. \& Watkinson, A. R. (2005). Accelerating impacts of temperature-induced coral bleaching in the Caribbean. Ecology. 86: 2055-2060.

Medina-Rosas, P., Carriquiry, J. D., Cupul-Magaña, A. L. \& Ixtapa, D. (2005). Recruitment of Porites (Scleractinia) on artificial substrate in reefs affected by the 1997-98 El Niño in Banderas Bay, Mexican Pacific. Ciencias Marinas. 31 (1A): 103-109.

Miller, M. W. (2015). Coral disturbance and recovery in a changing world. In C. Birkeland (ed.), Coral Reefs in the Anthropocene (p. 217-230). Dordrecht, The Netherlands: Springer.

Munro, J. L. (1983). Caribbean coral reef fishery resources. Manila, Philippines: ICLARM Studies and Reviews 7.

Muñoz, C. G., Wild, C. \& Zapata, F. A. (2015). Drift logs are effective agents of physical coral fragmentation in a tropical eastern Pacific coral reef. Bulletin of Marine Science. 91 (3): 375-376.

Nyström, M., Folke, C. \& Moberg, F. (2000). Coral reef disturbance and resilience in a human-dominated environment. Trends in Ecology and Evolution. 15: 413-417.

Palacios, M. M., Muñoz, C. G. \& Zapata, F. A. (2014). Fish corallivory on a pocilloporid reef and experimental coral responses to predation. Coral Reefs. 33 (3): 625-636.

Pandolfi, J. M. (1999). Response of Pleistocene coral reefs to environmental change over long temporal scales. American Zoologist. 39: 113-130.

Pandolfi, J. M., Bradbury, R. H., Sala, E., Hughes, T. P., Bjorndal, K. A., Cooke, R. G., McArdle, D., McClenachan, L., Newman, M. J. H., Paredes, G., Warner, R. R. \& Jackson, J. B. C. (2003). Global trajectories of the long-term decline of coral reef ecosystems. Science. 301: 955-957.

Pinheiro, J., Bates, D., DebRoy, S., Sarkar, D. \& R Core Team. (2017). nlme: Linear and Nonlinear Mixed Effects Models. $\mathrm{R}$ package version 3.1-131. Available at https://CRAN.Rproject.org/package $=$ nlme.

Porter, J. W., \& Meier, O. W. (1992). Quantification of loss and change in Floridian reef coral populations. American Zoologist. 32 (6): 625-640.

R Core Team. (2016). R: A language and environment for statistical computing. R Foundation for Statistical Computing, Vienna, Austria. Available in https://www.R-project.org/.
Rodríguez-Ramírez, A., Reyes-Nivia, M. C., Navas-Camacho, R., Bejarano, S., Garzón-Ferreira, J. \& Zapata, F. A. (2006). Status of the coral reefs of Colombia in 2003. Proceedings of the $10^{\text {th }}$ International Coral Reef Symposium. 976-981.

Rogers, C. S. (1985). Degradation of Caribbean and Western Atlantic coral reefs and decline of associated fisheries. Proceedings of the $5^{\text {th }}$ International Coral Reef Symposium. 6: 491-496.

Rouphael, A. B. \& Inglis, G. J. (2002). Increased spatial and temporal variability in coral damage caused by recreational scuba diving. Ecological Applications. 12: 427-440.

Santavy, D. L. \& Peters, E. C. (1997). Microbial pests: coral disease in the Western Atlantic. Proceedings of the $8^{\text {th }}$ International Coral Reef Symposium. 1: 607-612.

Smith, C. L. (1978). Coral reef fish communities: a compromise view. Environmental Biology of Fishes. 3 (1): 109-128.

Sutherland, K. P., Porter, J. W. \& Torres, C. (2004). Disease and immunity in Caribbean and Indo-Pacific zooxanthellate corals. Marine Ecology Progress Series. 266: 273-302.

Szmant, A. M. (2002). Nutrient enrichment on coral reefs: Is it a major cause of coral reef decline? Estuaries. 25: 743-766.

Vargas-Ángel, B., Zapata, F. A., Hernández, H. \& Jiménez, J. M. (2001). Coral and coral reef responses to the 1997-98 El Niño event on the Pacific coast of Colombia. Bulletin of Marine Science. 69: 111-132.

Warton, D. I. \& Hui, F. K. (2011). The arcsine is asinine: the analysis of proportions in ecology. Ecology. 92 (1): 3-10.

Wilkinson, C. R. (2008). Status of coral reefs of the world: 2008. Global Coral Reef Monitoring Network and Reef and Rainforest Research Centre, Townsville, Australia.

Williams, E. H. \& Bunkley-Williams, L. (1990). The worldwide coral reef bleaching cycle and related sources of coral mortality. Atoll Research Bulletin. 335: 1-71.

Zapata, F. A. (2001). Formaciones coralinas de isla Gorgona. In L. M. Barrios \& M. López-Victoria (eds.), Gorgona Marina: Contribución al conocimiento de una isla única (p. 27-40). Santa Marta, Colombia: INVEMAR, Serie de Publicaciones Especiales 7.

Zapata, F. A. \& Vargas-Ángel, B. (2003). Corals and coral reefs of the Pacific coast of Colombia. In J. Cortés (ed.), Latin America coral reefs (p. 419-447). Amsterdam, The Netherlands: Elsevier Science B.V.

Zapata, F. A., Rodríguez-Ramírez, A., Caro-Zambrano, C. \& Garzón-Ferreira, J. (2010). Mid-term coral-algal dynamics and conservation status of a Gorgona Island (Tropical Eastern Pacific) coral reef. Revista de Biología Tropical. 58: 81-94.

Zapata, F. A., Vargas-Ángel, B. \& Garzón-Ferreira, J. (2001). Salud y conservación de las comunidades coralinas. In L. M. Barrios \& M. López-Victoria (eds.). Gorgona Marina: Contribución al conocimiento de una isla única (p. 41-50). Santa Marta, Colombia: INVEMAR, Serie de Publicaciones Especiales 7.

Zea, S., Geister, J., Garzón-Ferreira, J. \& Díaz, J. M. (1998). Biotic changes in the reef complex of San Andrés Island (Southwestern Caribbean Sea, Colombia) occurring over nearly three decades. Atoll Research Bulletin. 456:1-30. 